\title{
Different response of perennial ryegrass_Epichloë endophyte symbiota to the elevated concentration of heavy metals in soil
}

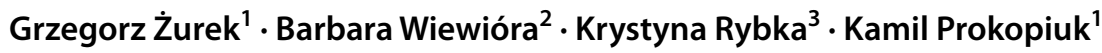

Received: 11 June 2021 / Revised: 5 August 2021 / Accepted: 31 August 2021 / Published online: 21 September 2021

(c) The Author(s) 2021

\begin{abstract}
The phenomenon of plant mutualistic symbiosis with microbes may have a positive effect on the improvement of plant tolerance to environmental stresses as well as on the ability of plants to accumulate heavy metal (HM) ions from soil. The influence of Epichloë fungal endophyte (Ascomycota, Clavicipitaceae) on perennial ryegrass (Lolium perenne L.) plants grown in the presence of elevated concentrations of $\mathrm{HM}$ ions $\left(\mathrm{Cd}^{2+}, \mathrm{Pb}^{2+}\right.$, and $\left.\mathrm{Cu}^{2+}\right)$ in soil was studied. The presence of Epichlö in the host grass tissues resulted in different accumulation of HM ions in the aboveground parts of the plants. In some cases, endophyte infection positively affected ryegrass ability to accumulate HM ions from soil. In plants with $(E+)$ and without $(E-)$ endophytes, the hormesis effect was induced by the elevated concentration of $\mathrm{Cu}^{2+}$ ions, resulting in better growth and photosynthesis, as examined by measurements of $\mathrm{Chl} a$ fluorescence. The obtained results indicate that based on the laboratory evaluation of the efficiency of HM accumulation, we were able to choose the best associations of perennial ryegrass with endophytes for HM phytoremediation.
\end{abstract}

Keywords Epichloë endophytes · Heavy metals $\cdot$ Perennial ryegrass $\cdot$ Photosynthesis $\cdot$ Phytoremediation $\cdot$ Soil pollution

\section{Introduction}

Endophytes can colonize plant tissues and live without inducing any visible symptoms of biotic stress in plants. In general, as a consequence of host plant-microbe interactions, these endophytes produce a range of alkaloids and stimulate the host plant for enhanced synthesis of primary and secondary metabolites, e.g., free sugars, sugar alcohols, proline, glutamic acid, phospholipids, proteins, and polysaccharides (Avila et al. 2012; Bush et al. 1997; Nagabhyru et al. 2013; Porter 1994; Rasmussen et al. 2008, Soto-Bajas

Communicated by: Izabela Pawłowicz

Barbara Wiewióra

b.wiewiora@ihar.edu.pl

1 Department of Grasses, Legumes and Energy Plants, Plant Breeding and Acclimatization Institute National Research Institute, Radzików, Poland

2 Department of Seed Science and Technology, Plant Breeding and Acclimatization Institute National Research Institute, Radzików, Poland

3 Department of Plant Physiology and Biochemistry, Plant Breeding and Acclimatization Institute National Research Institute, Radzików, Poland et al. 2016). Hao et al. (2010) observed that treatment of suspension cells of Ginkgo biloba with fungal endophytes resulted in the accumulation of flavonoids, increased abscisic acid (ABA) production, and activation of phenylalanine ammonia-lyase (PAL). Also, the root metabolism is altered in response to colonization of the aboveground parts of plants (Strehmel et al. 2016; Slaughter et al. 2018). Altogether, the mutual associations lead to changes in host plant gene expression and improve plant adaptations to environmental stresses, both biotic (e.g., insects, herbivore animals, diseases) and abiotic (e.g., drought) (Bacon et al. 2015; Dupont et al. 2015; Rodriguez et al. 2008; Schardl et al. 2012, 2013).

Inhibition of photosynthesis by heavy metals (HM) has been well documented (Clijsters and Van Assche 1985; Prasad and Strzałka 1999; Singh et al. 2011). HM stress induces a series of biochemical and physiological modifications in plant tissues that display common characteristics with those induced by drought. Membrane damage and altered enzyme activities lead to a wide range of secondary effects that concern practically all the physiological processes (Barceló and Poschenrieder 1990). Photosynthesis is a very sensitive process due to several structural and metabolic disturbances, like direct interactions of HM ions 
with thiol, histidyl- and carboxyl- groups of cell proteins, induction of reactive oxygen species (ROS) formation, and displacement of essential cations in protein active centers (Hall 2002; Hossain et al. 2012; Farid et al. 2013). Some ions such as $\mathrm{Hg}^{2+}, \mathrm{Cu}^{2+}, \mathrm{Cd}^{2+}, \mathrm{Ni}^{2+}$, or $\mathrm{Zn}^{2+}$ may substitute the central $\mathrm{Mg}^{2+}$ ion in chlorophyll molecules, forming complexes lowering the quantum efficiency of PSII (Van Assche and Clijsters 1990; Sharma and Dietz 2009). These circumstances affect most of the parameters of chlorophyll $a(\mathrm{Chl} a)$ fluorescence detected by the JIP test (Żurek et al. 2014). However, it has been demonstrated that endophytes play a key role in host plant adaptation to polluted environments and that they can enhance phytoremediation by mobilizing/degrading or immobilizing contaminants in the soil, promoting plant growth, decreasing phytotoxicity and improving plants' HM ion tolerance (Soleimani et al. 2010; Li et al. 2012a, b; Li et al. 2016).

Species of the fungal genus Epichloë (Ascomycota, Clavicipitaceae) are specialized fungi of cool-season grasses that can grow throughout the aerial parts of their host plants, forming systemic and predominantly asymptomatic associations, resulting in defensive mutualism (Clay 1988; Tadych et al. 2014). The importance of Epichloë endophytes for ecosystems due to modulation of both below- and aboveground ecosystem processes is well recognized and accepted (Saikkonen et al. 2016).

Phytoremediation is increasingly used as a sustainable approach for soil remediation. However, methodology improvement is constantly forced due to the expected increase in phytoremediation efficacy as well as due to economic reasons. Due to complex biological interactions, currently used methods do not always give the demanded results, so further multidirectional studies are needed (Thijs et al. 2017).

The aim of this study was to describe the different reaction of perennial ryegrass-Epichloë endophyte associations to the elevated concentration of lead, cadmium, and copper in soil with further possible application in the phytoremediation process.

\section{Materials and methods}

\section{Plant collection}

Ecotypes of perennial ryegrass (Lolium perenne L.) were collected from 12 localities in Poland in the form of living plants from permanent grasslands in most cases used for cattle feeding. The term "ecotype" refers to a group of plants within a species that is adapted to particular environmental conditions (locality) and therefore exhibiting structural or physiological differences from the other members of the same species. Those areas were located in Podlaskie (POD), Mazowieckie (MAZ), Lubelskie (LUB), and Świętokrzyskie (SWK) regions located on Central European Plain, in Poland. (Fig. 1, Tab. 1, Supp. Tab.1).

From five to ten plants were picked up in each locality, with the distances of 5-10 $\mathrm{m}$ from each other, to avoid collecting clones. GPS coordinates of each locality were recorded. Average concentration of $\mathrm{Pb}^{2+}, \mathrm{Cu}^{2+}$, and $\mathrm{Cd}^{2+}$
Fig. 1 Map of the distribution of ecotype collection sites in regions of Poland: POD (Podlaskie), MAZ (Mazowieckie), $L U B$ (Lubelskie), $S W K$ (Świętokrzyskie). Ecotypes are identified by reference numbers the same across the whole manuscript. Map drawn with the DIVA-GIS ver. 7.1.7 software (http:///www.diva-gis.org)

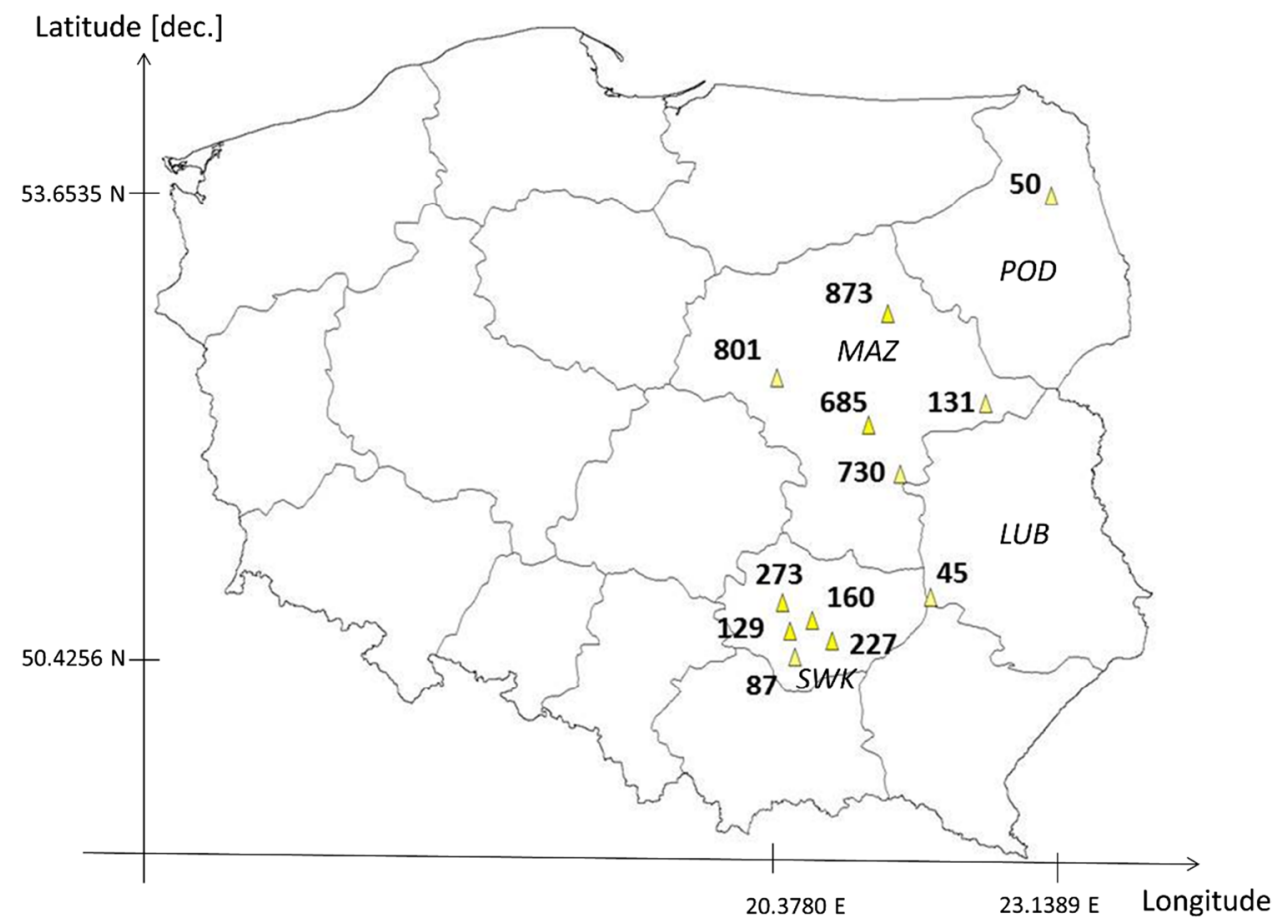


Table 1 Analysis of variance for the effect of ecotype, HM presence in soil and endophyte on yield of aerial parts of plants and CCI values. $F$ values were given and significance of the effects and interactions with probability higher than $99.9 \%$ $(* * *)$ or $95 \%(* *)$

\begin{tabular}{|c|c|c|c|c|c|}
\hline \multirow[t]{2}{*}{ Source of variation } & \multicolumn{4}{|c|}{ Aboveground biomass collected in: } & \multirow[t]{2}{*}{$\mathrm{CCI}$} \\
\hline & 1 st cut & 2nd cut & 3 rd cut & All cuts (sum) & \\
\hline \multicolumn{6}{|l|}{ Main effects: } \\
\hline Ecotype [1] & $2.75^{* *}$ & $3.64^{* * *}$ & $0.86^{\mathrm{ns}}$ & $1.94^{* *}$ & $2.94^{* * *}$ \\
\hline $\mathrm{HM}$ in soil [2] & $97.05^{* * *}$ & $867.79^{* * *}$ & $205.01^{* * *}$ & $455.9^{* * *}$ & $98.90^{* * *}$ \\
\hline Endophyte presence [3] & $4.03^{* *}$ & $5.86^{* *}$ & $0.05^{\mathrm{ns}}$ & $0.05^{\mathrm{ns}}$ & $2.41^{\mathrm{ns}}$ \\
\hline \multicolumn{6}{|l|}{ Interactions } \\
\hline Ecotype $\times$ HM & $2.36^{* *}$ & $1.90^{* *}$ & $0.91^{\mathrm{ns}}$ & $1.72^{\mathrm{ns}}$ & $4.05^{* * *}$ \\
\hline Ecotype $\times$ endophyte pres & $0.85^{\mathrm{ns}}$ & $1.62^{\mathrm{ns}}$ & $1.15^{\mathrm{ns}}$ & $1.39^{\mathrm{ns}}$ & $0.95^{\mathrm{ns}}$ \\
\hline $\mathrm{HM} \times$ endophyte pres & $0.30^{\mathrm{ns}}$ & $2.60^{\mathrm{ns}}$ & $2.06^{\mathrm{ns}}$ & $0.78^{\mathrm{ns}}$ & $0.01^{\mathrm{ns}}$ \\
\hline$[1] \times[2] \times[3]$ & $1.23^{\mathrm{ns}}$ & $1.62^{\mathrm{ns}}$ & $0.81^{\mathrm{ns}}$ & $1.34^{\mathrm{ns}}$ & $1.78^{\mathrm{ns}}$ \\
\hline
\end{tabular}

ions in soils for regions of collection sites were given as per Terelak (2007).

Since plants in the described experiment were part of a large collection, their numbering has no ordinal values. Collected ecotypes were further replanted in a spaced nursery, with $0.5 \mathrm{~m}$ distances between plants in Radzików, Poland $(52.21 \mathrm{~N} ; 20.64 \mathrm{E})$. No additional treatments (fertilization, watering, chemical weed control) were applied.

\section{Endophyte detection}

Perennial ryegrass-Epichloë endophyte associations were identified by the rapid staining method according to Saha et al. (1988). Fungal hyphae $(E+)$, appeared as an intercellular, long, and convoluted hyphae parallel to the leaf-sheath axis of the plant cell without forming haustorial structures (Clay and Holah 1999), (Supp. Fig. S1). On the bases of our recent discoveries and work done on perennial ryegrass endophytes (Wiewióra et al. 2015a, 2015b), fungus forming fungal hyphae inside intercellular spaces were described as belonging to genus Epichloë (Clavicipitaceae). Based on studies with confirmed isolates describing the typical fungal hyphae in the intercellular space of infected tissues from perennial ryegrass, and our own recent studies, we refer to the endophyte found in Polish perennial ryegrass as Epichloë festucae spp. lolii.

Twelve ecotypes with $E+$ plants were selected as material for further studies. Seeds were collected only from $E+$ plants of those ecotypes grown in the nursery and again tested for the presence of the endophyte hyphae using the rose bengal staining method (Saha et al. 1988). Half of the seeds from each ecotype was treated with Tebuconazole (placing the seeds in a liquid suspension), a triazole fungicide to remove the endophyte from seed bulk ( $E-$ ). Both $E+$ and $E$ - seeds were sown on filter paper and seedlings were transferred to 0.51 pots filled with mixture $(1: 2)$ of sterilized sand and peat. Seedlings were grown in pots for 4 weeks, with frequent watering and without additional fertilization.
The presence/absence of the endophyte hyphae was again confirmed on 3-4 weeks old seedlings by rose bengal staining before microscopic examination of 3 tillers per each plant. For each ecotype, $12 E-$ and $12 E+$ plants were vegetatively propagated: half of each set was intended for HM treatment and half remained as a control (no HM). As a result of the final round of vegetative propagation, 24 plants per ecotype $E+$ and the same number per $E$ - were used in the experiment run in fourfold repetitions per 3 plants each. Again, the endophyte status $(E+/ E-)$ was checked.

\section{Pot experiment}

From each ecotype for both $E+$ and $E$ - forms, 24 plants were planted, 3 in one $1.5 \mathrm{~L}$ pot containing a mixture (1:2) of sterilized sand and peat substrate of the final content of: 95.1 N; 150.2 $\mathrm{P}_{2} \mathrm{O}_{5} ; 153.3 \mathrm{~K}_{2} \mathrm{O} ; 55.5 \mathrm{MgO} ; 7.7 \mathrm{~Pb}^{2+} ; 0.2$ $\mathrm{Cd}^{2+}$; and $2.4 \mathrm{Cu}^{2+}\left[\mathrm{mg} \cdot \mathrm{kg}^{-1}\right.$ of dry substrate $] ; \mathrm{pH}=6.1$ and $13 \%$ of soil organic carbon (SOC).

The pot experiment was arranged into a randomized complete block design with 4 blocks, where each ecotype was grown in 4 pots per block ( 3 plants per pot): two pots with $E+$ plants and two pots with $E$-plants. From those four pots, two were treated with HM solution (see below) and two were control. Pots in blocks were re-arranged during the experiment to reduce the positional effect and reduce the residual or pot-to-pot variance. Therefore, two factors were used in the aforementioned experiment: the first, endophyte infection ( $E+$ and $E$-plants) and the second, HM treatment.

The experiment was run in a glasshouse, starting from late spring for 16 weeks in total, with the first 7 weeks of HM treatment. Seedlings were planted into pots, and after 3 weeks of growth in the glasshouse, the first watering was applied; then, watering was applied 9 times during the next 36 days of growth. Control pots were watered with distilled water. Intervals between watering usually were 4-5 days. The whole watering brought in total $20 \mathrm{mg}$ of $\mathrm{Cd}^{2+}$ and $700 \mathrm{mg}$ of both $\mathrm{Pb}^{2+}$ and $\mathrm{Cu}^{2+}$ ions in $1 \mathrm{~kg}^{-1}$ of the used substrate. Finally, HM ion concentration in the substrate, as 
determined by Regional Agrochemical Station in Warsaw (accredited laboratory acc. PN-EN ISO/IEC 17,025:2005), reached: $15.5 \mathrm{Cd}^{2+} ; 550.9 \mathrm{~Pb}^{2+} ; 546.0 \mathrm{Cu}^{2+}\left[\mathrm{mg} \cdot \mathrm{kg}^{-1}\right]$.

\section{Analysis of biomass yields, relative chlorophyll contents, and $\mathrm{Chl}$ a fluorescence parameters}

Biometric phenotyping of the aboveground part of plants was done to determine the rate of plant growth. Three cuts of plants from all experimental pots were done after 1,2, and 4 months of plant growth in pots since planting, followed by drying at $70{ }^{\circ} \mathrm{C}$ for 3 days for determination of dry matter yield. Dry biomass from each pot was collected to determine HM concentration in plants.

Chlorophyll content index (CCI) was measured with CCM200 Plus (PSI, Brno, Czech Republic), on 3 leaves per plant for a total of 24 plants of both forms $E+$ and $E-$ of each ecotype. The single result consisted of five single measurements per leaf.

Chlorophyll $a(\mathrm{Chl} a$ ) fluorescence was measured using PocketPEA portable fluorimeter (Hansatech Instruments, King's Lynn, Norfolk, UK). Three measurements per plant (3 plants per ecotype per replication per variant) were done. Fluorescence was induced by saturating, red actinic light with energy of $3.500 \mu \mathrm{mol} \cdot \mathrm{m}^{-2} \cdot \mathrm{s}^{-1}$. Measured and calculated parameters were used for the interpretation of endophyteplant interaction in the presence of HM ions (Paunov et al. 2018). Measured parameters: $F_{\mathrm{O}} \approx F_{50 \text { us }}$ [minimal fluorescence]; $F_{\mathrm{M}}=F_{\mathrm{P}}$ [maximal recorded fluorescence]; $T_{\mathrm{FM}}$ [time (in ms) to reach the maximal fluorescence, $F_{\mathrm{M}}$ ]; Area [total complementary area between the fluorescence induction curve and $F_{\mathrm{M}}$ of OJIP curve]. Parameters calculated and listed by the PocketPEA software: $F_{\mathrm{V}}$ [maximal variable fluorescence calculated as $F_{\mathrm{M}}-F_{\mathrm{O}}$ ]; $F_{\mathrm{V}} / F_{\mathrm{M}}$ [force of the light reactions]; RC/ABS [the amount of active reaction centers per absorption]; $\left(1-V_{\mathrm{J}}\right) / V_{\mathrm{J}}$ [measure of forward electron transport]; $\mathrm{PI}_{\mathrm{ABS}}$ [performance index]. The above measurements (CCI and $\mathrm{Chl} a$ ) were done 2 weeks after the last $\mathrm{HM}$ ions dosing.

\section{Chemical analysis}

Determination of HM concentration in plants and soil were done as described previously (Żurek et al. 2014) by Regional Agrochemical Station in Warsaw (accredited laboratory acc. PN-EN ISO/IEC 17,025:2005). Plant material was washed with tap water and then with deionized water in an ultrasonic washer to remove all soil particles followed by drying at $70{ }^{\circ} \mathrm{C}$ for 3 days. Three hundred $\mathrm{mg}$ of dried, ground plant material was wet-washed using concentrated nitric acid (Merck) in a microwave system (MDS 2000, CEM, USA).

For determination of total $\mathrm{HM}$ ion $\left(\mathrm{Cd}^{2+}, \mathrm{Pb}^{2+}\right.$, and $\left.\mathrm{Cu}^{2+}\right)$ concentration in soil, extraction of air-dried soil samples was taken at the end of the experiment from each pot, ground to $<0.25 \mathrm{~mm}$ and extracted with concentrated perchloric $\left(\mathrm{HClO}_{4}\right)$ and fluoric $(\mathrm{HF})$ acids. The amount of $\mathrm{Cd}^{2+}, \mathrm{Pb}^{2+}$, and $\mathrm{Cu}^{2+}$ ions were measured using inductively coupled plasma spectrometry (ICP-AES, Spectro Analytical Instruments GmbH, Kleve, Germany).

\section{Statistical analysis}

All calculations were made with STATISTICA® 12 for Windows (StatSoft Inc. 2014). The significance of differences was accepted with a $95 \%$ probability. Two-way factorial ANOVA analysis was performed with ecotypes, presence of HM in soil, and endophyte presence in plants applied as main factors. Least significant differences (LSD) were calculated according to the Fisher test. $T$ tests were performed at independent samples mode for HM ion contents in leaves of $E+$ and $E-$. Principal component analysis (PCA) based on the correlation matrix algorithm was performed for all chlorophyll fluorescence traits measured and calculated for all ecotypes.

\section{Results}

\section{Plant collection sites}

Most of the soil beneath meadows from which perennial ryegrass plants were derived, were of mineral or organic type, with medium or low soil moisture content, mainly with medium or low-intensity usage as pastures or for cutting (Supp. Table 1). All regions except one (SWK) were characterized by relatively low concentrations of $\mathrm{HM}$ ions in soil: $\mathrm{Pb}^{2+}$, c.a. 9.6; $\mathrm{Cd}^{2+}, 0.17$; and $\mathrm{Cu}^{2+}, 4.3\left[\mathrm{mg} \cdot \mathrm{kg}^{-1}\right]$. Much higher (almost doubled) concentrations of HM ions have been reported by Terelak (2007) for the SWK region: $\mathrm{Pb}^{2+}$, c.a. 17.8; $\mathrm{Cd}^{2+}, 0.37$; and $\mathrm{Cu}^{2+}, 7.6\left[\mathrm{mg} \cdot \mathrm{kg}^{-1}\right.$ ] (Fig. 1, Supp. Table 1).

\section{Analysis of biomass yields, relative chlorophyll contents, and $\mathrm{Chl}$ a fluorescence parameters}

Biomass yields were significantly affected by the ecotype and HM treatment throughout the whole experiment whereas the main effect of the endophyte was significant only for the first (after a month) and second cuts (after two months) (Table 2).

Generally, for plants grown in the presence of HM ions, dry matter yields combined for three cuts were higher $(3.1 \mathrm{~g} /$ plants) than for control plants (1.3-1.5 g/plants) irrespective of endophyte presence in plants (Fig. 2, Supp. Figure 2). The yield of plants grown in the presence of HM, despite the presence of endophyte in plants, was $48 \%$ higher than control 
Table 2 Analysis of variance for the effect of ecotype, HM presence in soil and endophyte presence in plants on selected parameters of Chl $a$ fluorescence $\left(F_{\mathrm{O}}, F_{\mathrm{M}}, F_{\mathrm{V}}, F_{\mathrm{V}} / F_{\mathrm{M}}, F_{\mathrm{V}} / F_{\mathrm{O}},(1-V \mathrm{j}) / V \mathrm{j}\right) . F$ values were given and significance of the effects and interactions with prob- ability higher than $99.9 \%(* * *)$ or $95 \%(* *)$. For $T_{\mathrm{FM}}$, RC/ABS, and $\mathrm{PI}_{\mathrm{ABS}}, F$ values for none of main effects or their interactions were significant; therefore, mentioned parameters were not listed below

\begin{tabular}{|c|c|c|c|c|c|c|c|}
\hline \multirow[t]{2}{*}{ Source of variation } & \multicolumn{7}{|c|}{ Chl a fluorescence parameters } \\
\hline & $F_{\mathrm{O}}$ & $F_{\mathrm{M}}$ & $F_{\mathrm{V}}$ & $F_{\mathrm{V}} / F_{\mathrm{M}}$ & $F_{\mathrm{V}} / F_{\mathrm{O}}$ & $(1-V \mathrm{j}) / V \mathrm{j}$ & Area \\
\hline \multicolumn{8}{|l|}{ Main effects } \\
\hline Ecotype [1] & ns & ns & ns & ns & ns & ns & ns \\
\hline $\mathrm{HM}$ in soil [2] & $57.67^{* * * *}$ & $31.48^{* * * *}$ & $24.66^{* * *}$ & $16.70^{* * *}$ & $18.25^{* * *}$ & $9.23^{* *}$ & ns \\
\hline Endophyte presence [3] & ns & ns & ns & ns & ns & ns & ns \\
\hline \multicolumn{8}{|l|}{ Interactions } \\
\hline$[1] \times[2]$ & ns & $\mathrm{ns}$ & ns & $\mathrm{ns}$ & $\mathrm{ns}$ & $\mathrm{ns}$ & ns \\
\hline$[1] \times[3]$ & ns & ns & ns & ns & ns & ns & ns \\
\hline$[2] \times[3]$ & $27.16^{* * *}$ & $13.66^{* * * *}$ & $10.36^{* *}$ & $7.10^{* *}$ & $9.51^{* *}$ & ns & $15.47^{* * *}$ \\
\hline$[1] \times[2] \times[3]$ & ns & ns & ns & $1.90^{* *}$ & ns & $2.19^{* *}$ & ns \\
\hline
\end{tabular}

Fig. 2 Average yields of dry biomass collected from young plants of perennial ryegrass with $(E+)$ and without $(E-)$ endophytes, grown in soil treated or not treated with HM Error bar for the sum of 3 cuts

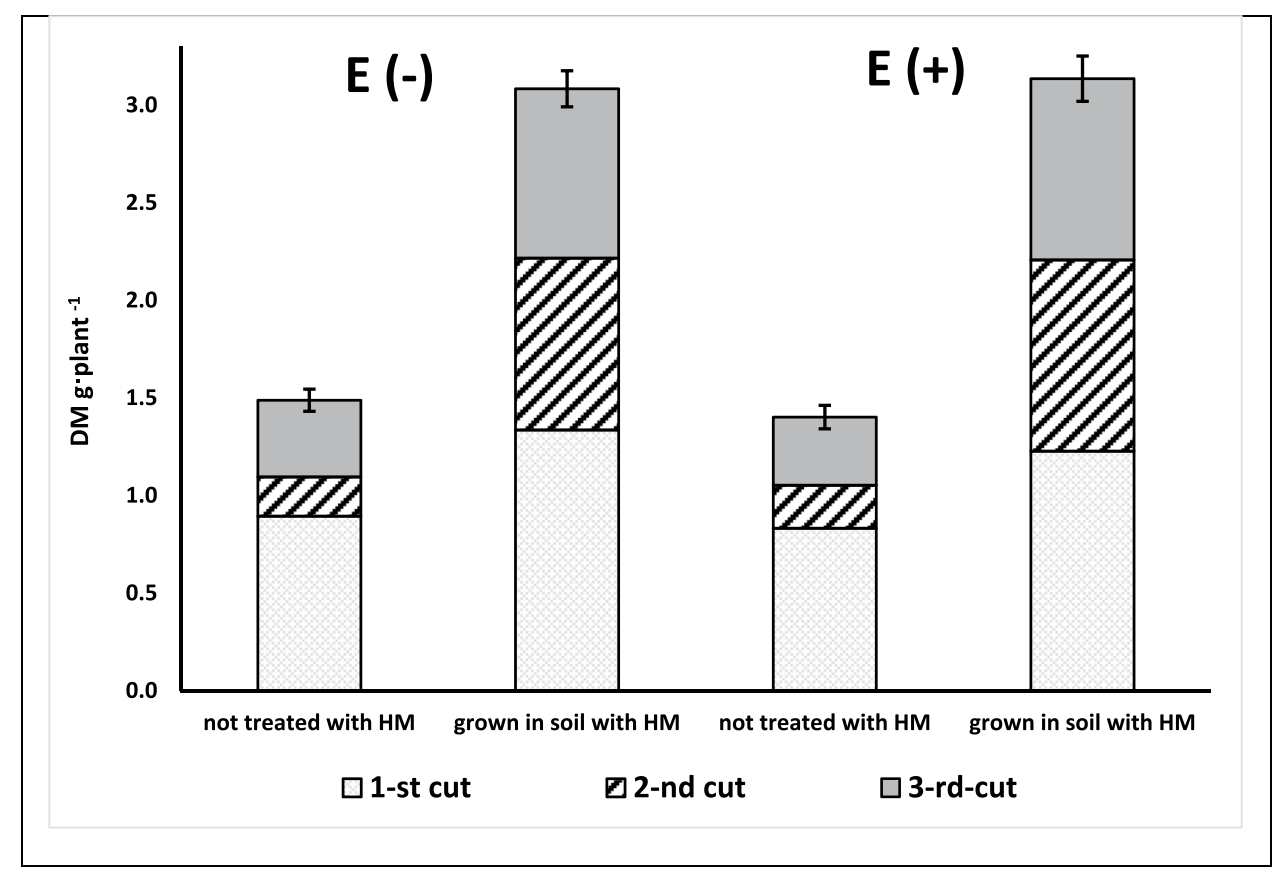

at 1 st cut, $342 \%$ at 2 nd, and $143 \%$ at 3 rd cut on average. For the whole experiment, the total yield from HM treated plants was $115 \%$ higher than that of the control plants. This difference was statistically significant $(p=0.0000 ; F=387.26)$.

Elevated concentrations of the HM in the soil, as well as the provenance of the tested ecotypes, were the main sources of variation for the relative chlorophyll content, expressed as $\mathrm{CCI}$. In contrast, neither endophyte presence nor its interaction with the plant provenance and HM gave a significant effect on the CCI (Table 2). The CCI in HM treated ecotypes was on average higher than in non-HM treated ones (Fig. 3) and above difference was also significant $(p=0.0000$; $F=86.21$ ).
Elevated concentration of the HM in the soil was also the main source of variation of Chl $a$ fluorescence parameters: $F_{\mathrm{O}}, F_{\mathrm{M}}, \mathrm{F}_{\mathrm{V}}, F_{\mathrm{V}} / F_{\mathrm{M}}, F_{\mathrm{V}} / F_{\mathrm{O}}$, and $(1-V \mathrm{j}) / V \mathrm{j}$ (Table 3, Supp. Figure 3).

Neither the ecotype nor endophyte status resulted in a significant effect of any of the abovementioned Chl a fluorescence parameters. However, a significant interaction between HM presence in soil and endophyte presence in plants has been calculated for $F_{\mathrm{O}}, F_{\mathrm{M}}, F_{\mathrm{V}}, F_{\mathrm{V}} / F_{\mathrm{M}}, F_{\mathrm{V}} / F_{\mathrm{O}}$, and Area (Table 3, Fig. 4). For the parameters $T_{\mathrm{FM}}, \mathrm{RC} /$ $\mathrm{ABS}$, and $\mathrm{PI}_{\mathrm{ABS}}$, none of the main sources of variation nor interactions were significant; therefore, they were not listed in Table 3 and Fig. 4. 
Fig. 3 Mean values of chlorophyll contents index $(\mathrm{CCI})$ in perennial ryegrass $(E-)$ plants and Epichlö̈-perennial ryegrass symbiota $(E+)$ grown in control conditions (left bar for each ecotype) and in the presence of HM ions (right bar for each ecotype)

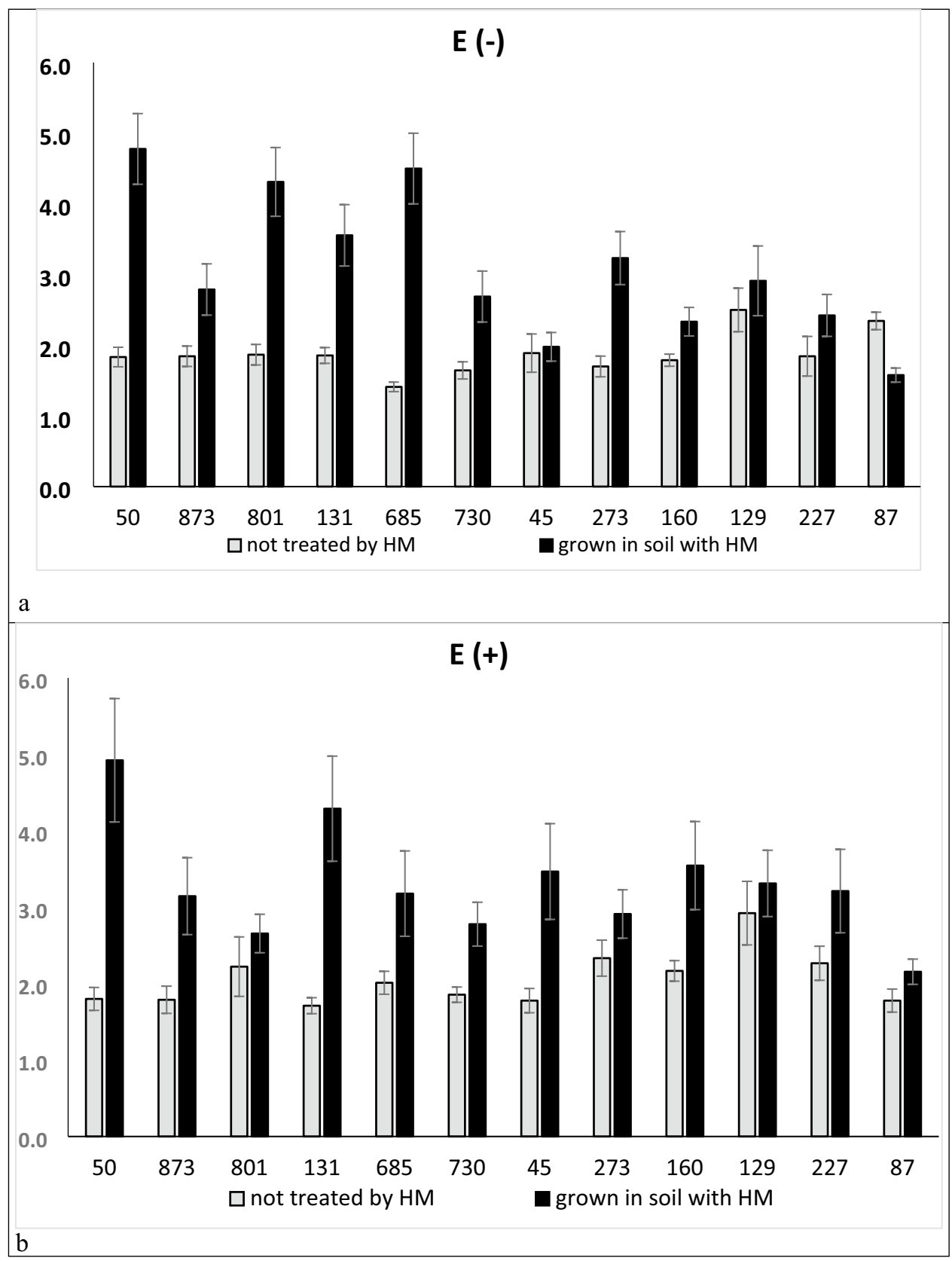

Table 3 Analysis of variance for the effect of ecotypes, endophyte presence in the host plant and their interaction on the content of HM ions in leaves of $E+$ (perennial ryegrass colonized by Epichloë endophyte) and $E$-(endophyte free perennial ryegrass). $F$ values were given and significance of the effects, with probability higher than $99.9 \%(* * *)$

\begin{tabular}{llll}
\hline HM ion content & & & \\
\hline Source of variation & $\mathrm{Pb}^{+2}$ & $\mathrm{Cd}^{+2}$ & $\mathrm{Cu}^{+2}$ \\
\hline Ecotype [1] & $124.94 * * *$ & $31.26 * * *$ & $47.87 * * *$ \\
Endophyte presence [2] & $\mathrm{ns}$ & $139.48 * * *$ & $180.79 * * *$ \\
Interaction [1] $\times[2]$ & $210.84 * * *$ & $39.22 * * *$ & $95.03 * * *$ \\
\hline
\end{tabular}

Considering interactions presented in Fig. 4, perennial ryegrass plants, if grown without the addition of HM, exhibited some negative effects of endophyte presence in tissues, as reflected in lower values of $F_{\mathrm{M}}, F_{\mathrm{V}}$, and higher for Area. When HM was added to the soil medium, values of the mentioned parameters increased in the presence of endophytes. However, the value of the parameter reflecting the force of light reactions of PS II $\left(F_{\mathrm{V}} / F_{\mathrm{M}}\right)$ was significantly lower in the presence of HM in soil and endophytes in plant tissues. Therefore, whether $E+$ plants score higher or lower values of mentioned Chl $a$ parameters than $E$ - plants depends on the addition of HM to the soil medium. 


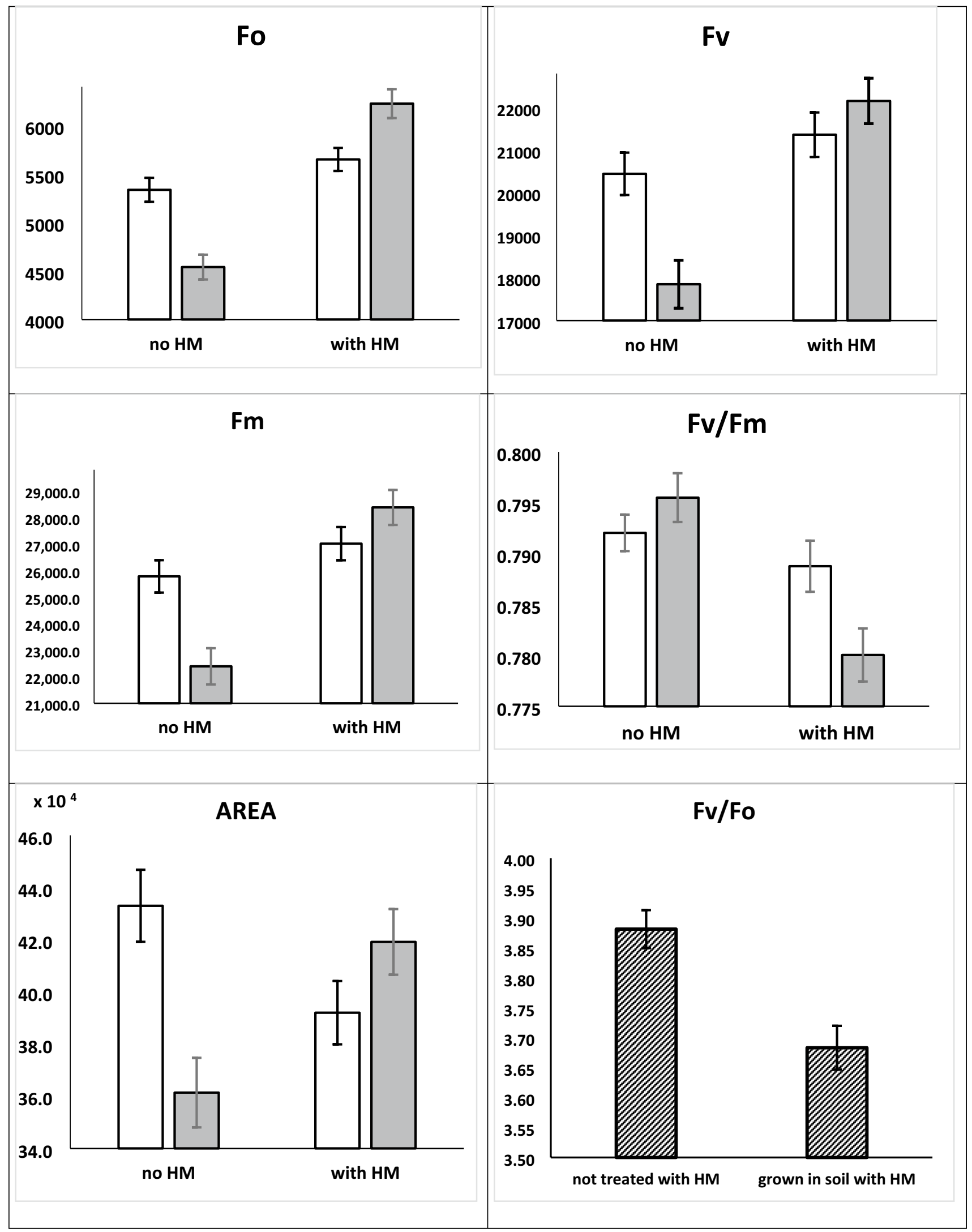

Fig. 4 The effect of HM treatment of perennial ryegrass plants on chlorophyll $a$ fluorescence parameters, which differed in statistically important manner: $F_{\mathrm{O}}, F_{\mathrm{V}}, F_{\mathrm{M}}$, Area, $F_{\mathrm{V}} / F_{\mathrm{M}}, F_{\mathrm{V}} / F_{\mathrm{O}}$. Bars on graph indicate standard error of means. For $F_{\mathrm{O}}, F_{\mathrm{V}}, F_{\mathrm{M}}$ arbitrary units were used 
Measured parameters of $\mathrm{Chl} a\left(F_{\mathrm{O}}, F_{\mathrm{M}}, F_{\mathrm{V}}\right)$ were influenced by HM treatment (Table 3, Supp. Figure 3). Interestingly, $E+$ plants collected in more northern localities were characterized by a more visible decline of $F_{\mathrm{V}} / F_{\mathrm{M}}$ and $F_{\mathrm{V}} / F_{0}$ ratios. And, as in the case of measured parameters, $E+$ ecotype 730 reacted differently, by their slight increase. The ratio of $F_{\mathrm{V}} / F_{0}$ was $\leq 4.0$ in $E$ - plants, whereas in $E+$ plants in 3 cases, the ratio exceeded 4 (ecotypes 45 , 87 , and 873). Parameter $\left(1-V_{\mathrm{j}}\right) / V_{\mathrm{j}}$, the measure of forward electron transport, seemed to be slightly affected by HM, especially in the leaves of $E+$ plants.

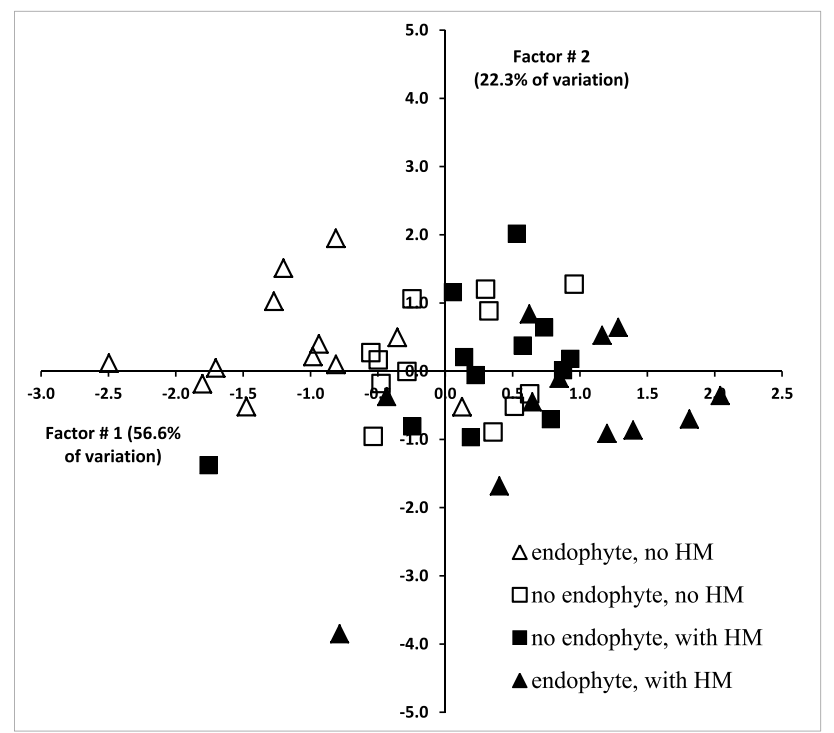

Fig. 5 The graphical presentation of PCA analysis results based on measurements of Chl $a$ parameters for ryegrass-Epichloë symbionts, grown with or without HM supplementation. Each data point represents a different ecotype
The PCA (principal component analysis) run on the bases of Chl $a$ fluorescence parameters have shown the distribution of ecotypes depending on the endophyte presence mostly over the OX axis (first factor) (Fig. 5, Supp. Table 2) which means that most of the measured parameters, significantly correlated with the first factor $\left(F_{0}, F_{\mathrm{V}}, F_{\mathrm{M}}\right.$, and Area), influenced such grouping.

Ecotypes with endophytes, grown in soil without HM, were separated on the left side of the graph, as opposed to $E+$ grown with the addition of HM. Negative values of factor 1 , which is negatively correlated with $F_{0}, F_{\mathrm{V}}, F_{\mathrm{M}}$, and Area, were ascribed to increased values of the mentioned $\mathrm{Chl} a$ parameters. On the right side of the OX axis, along with decreasing values of $\mathrm{Chl} a$ parameter, points representing $E+$ plants grown with the addition of HM were located. This is another presentation of the interaction between HM and endophyte presence.

\section{$H M$ ion content in $E+$ and $E$ - ecotypes}

Analysis of variance for the data of HM ion concentration in the plant tissue revealed a statistically significant influence of both: plant provenance and endophyte presence in the host plant as well as their interaction in case of $\mathrm{Cd}^{+2}$ and $\mathrm{Cu}^{+2}$ ion concentration (Table 4).

The highest concentration of $\mathrm{HM}$ ions (sum of $\mathrm{Pb}^{2+}$, $\mathrm{Cd}^{2+}$, and $\left.\mathrm{Cu}^{2+}\right)$ was detected in the leaves of $E+$ variant of ecotype $160\left(102 \mathrm{mg} \cdot \mathrm{kg}^{-1}\right)$, whereas in the leaves of the $E$ - plants, the concentration of $\mathrm{HM}$ was low $\left(44 \mathrm{mg} \cdot \mathrm{kg}^{-1}\right)$ (Table 5). Differences in the particular ion concentration of the abovementioned ecotype were as follows: almost twofold higher concentration of $\mathrm{Pb}^{2+}$ and $\mathrm{Cd}^{2+}$ ions and threefold of $\mathrm{Cu}^{2+}$ in $E$ + plants compared to $E-$.

The highest concentration of $\mathrm{Pb}^{2+}\left(43.9 \mathrm{mg} \bullet \mathrm{kg}^{-1}\right)$ was detected in the $E$-plants of ecotype 50 from POD region,
Table 4 Mean values of the $\mathrm{HM}$ ions $\left(\mathrm{Pb}^{+2}, \mathrm{Cd}^{+2}, \mathrm{Cu}^{+2}\right.$; $\left.\mathrm{mg} \cdot \mathrm{kg}^{-1}\right)$ contents in leaves of $E+$ (perennial grass colonized by Epichlö̈ sp. endophyte) and $E$ - (endophyte free perennial ryegrass) plants and the results of $\mathrm{t}$-test for independent samples. Ecotypes were listed in decreasing order of collection sites latitude

\begin{tabular}{|c|c|c|c|c|c|c|c|c|c|}
\hline \multirow[t]{2}{*}{ Ecotype number } & \multicolumn{3}{|l|}{$\mathrm{Pb}^{+2}$} & \multicolumn{3}{|l|}{$\mathrm{Cd}^{+2}$} & \multicolumn{3}{|c|}{$\mathrm{Cu}^{+2}$} \\
\hline & $E-$ & $E+$ & $t$ & $E-$ & $E+$ & $t$ & $E-$ & $E+$ & $t$ \\
\hline 50 & 43.9 & 15.7 & $154.5^{* * *}$ & 11.8 & 12.3 & n.s & 34.7 & 14.6 & $8.0^{* *}$ \\
\hline 873 & 16.5 & 32.7 & $-6.8^{* *}$ & 8.4 & 8.8 & n.s & 10.1 & 37.4 & $-47.1^{* * * *}$ \\
\hline 801 & 21.0 & 21.4 & n.s & 10.3 & 19.8 & $-18.3^{* * *}$ & 15.4 & 15.1 & n.s \\
\hline 131 & 29.3 & 11.0 & $42.1^{* * * *}$ & 14.8 & 10.3 & $7.2^{* *}$ & 23.1 & 13.8 & $9.8^{* *}$ \\
\hline 685 & 29.9 & 33.2 & $-5.0^{* *}$ & 8.0 & 15.1 & $-34.6^{* * *}$ & 20.9 & 26.5 & $-2.9^{*}$ \\
\hline 730 & 20.8 & 10.2 & $27.5^{* * *}$ & 7.1 & 8.1 & $-6.7^{* *}$ & 15.1 & 14.6 & n.s \\
\hline 45 & 32.6 & 23.3 & $12.1^{* * * *}$ & 9.1 & 16.2 & $-5.2^{* *}$ & 25.7 & 30.8 & $-3.7^{* *}$ \\
\hline 273 & 16.0 & 28.8 & $-23.8^{* * *}$ & 11.8 & 10.8 & $3.4^{*}$ & 14.7 & 40.6 & $-18.4^{* * * *}$ \\
\hline 160 & 20.2 & 40.7 & $-15.3^{* * *}$ & 7.4 & 13.4 & $-9.2^{* * *}$ & 16.2 & 47.9 & $-17.5^{* * *}$ \\
\hline 129 & 13.4 & 24.4 & $-10.7^{* * *}$ & 10.3 & 13.4 & $-11.2^{* * *}$ & 19.7 & 20.9 & $-2.8^{*}$ \\
\hline 227 & 10.4 & 18.9 & $-14.0^{* * * *}$ & 12.1 & 9.1 & $9.5^{* * *}$ & 14.0 & 19.6 & $-6.4^{* *}$ \\
\hline 87 & 24.6 & 20.2 & $6.0^{* * *}$ & 10.2 & 12.3 & n.s & 21.3 & 22.1 & n.s \\
\hline Mean & 23.2 & 23.4 & n.s & 10.1 & 12.4 & $-3.44^{* * *}$ & 19.2 & 25.8 & $-2.8^{* * *}$ \\
\hline
\end{tabular}


Table 5 Geographical description of ecotype collection sites: decimal coordinates of northern latitude $[\mathrm{N}]$ and eastern longitude [E], elevation above sea level [m.a.s.l.]. The percentage share of endophyte colonized plants (Ee [\%]) in each locality was shown in the last column. Ecotypes are identified by reference numbers the same across the whole manuscript

\begin{tabular}{lllllr}
\hline Region (code) & $\begin{array}{l}\text { Ecotype } \\
\text { number }\end{array}$ & \multicolumn{2}{l}{ Coordinates [decimal] } & \multirow{2}{*}{$\begin{array}{c}\text { Elevation } \\
\text { [m.a.s.1.] }\end{array}$} & Ee [\%] \\
\cline { 3 - 4 } & & Latitude [N] & Longitude [E] & & \\
\hline Podlaskie (POD) & 50 & 53.653 & 23.138 & 118 & 57.4 \\
Mazowieckie (MAZ) & 873 & 52.826 & 21.494 & 100 & 98.1 \\
& 801 & 52.374 & 20.378 & 69 & 61.1 \\
& 131 & 52.195 & 22.482 & 150 & 87.0 \\
& 685 & 52.046 & 21.301 & 80 & 70.4 \\
Lubelskie (LUB) & 730 & 51.705 & 21.617 & 128 & 64.8 \\
Świętokrzyskie (SWK) & 45 & 50.840 & 21.924 & 155 & 94.4 \\
& 273 & 50.802 & 20.435 & 283 & 70.4 \\
& 160 & 50.682 & 20.732 & 284 & 98.1 \\
& 129 & 50.604 & 20.506 & 187 & 100.0 \\
& 227 & 50.539 & 20.935 & 185 & 64.2 \\
& 87 & 50.425 & 20.559 & 172 & 90.6 \\
\hline
\end{tabular}

whereas the lowest $\left(10.2 \mathrm{mg} \bullet \mathrm{kg}^{-1}\right)$, in the $E+$ variant of ecotype 730 from MAZ region. The average value of $\mathrm{Pb}^{2+}$ for regions was the lowest for $E$ - variants of plants from SWK region $\left(16.9 \mathrm{mg} \bullet \mathrm{kg}^{-1}\right)$, but it was also the highest $\left(26.6 \mathrm{mg} \cdot \mathrm{kg}^{-1}\right)$ for $E+$ plants from the same region. Considering $E+$ plants, the highest $\mathrm{Pb}^{2+}$ concentration $\left(40.7 \mathrm{mg} \cdot \mathrm{kg}^{-1}\right)$ was detected in ecotype 160 , and was also high in ecotypes 685 and 873 (33.2 and $32.7 \mathrm{mg} \bullet \mathrm{kg}^{-1}$, respectively). For all those three mentioned ecotypes, $\mathrm{Pb}^{2+}$ concentration in $E+$ plants was significantly higher than in $E$ - plants. But at the same time, for other ecotypes $(50,131,730,45$, and 87$)$, the $\mathrm{Pb}^{2+}$ ion concentration was higher in $E$ - plants than in $E+$.

Cadmium concentration in aerial parts of $E+$ ecotypes was the highest in ecotype $801\left(19.8 \mathrm{mg} \mathrm{kg}^{-1}\right)$ as well as in ecotypes: 45 and 685 (16.2 and $15.1 \mathrm{mg} \mathrm{kg}^{-1}$, respectively) (Table 5). In a manner similar to relations described above for $\mathrm{Pb}^{2+}$ concentration, for all three ecotypes with relatively high $\mathrm{Cd}^{2+}$ concentration in $E+$ plants, the $\mathrm{Cd}^{2+}$ ion concentration was significantly higher than the concentration values found in $E$-plants. Average concentration of $\mathrm{Cd}^{+2}$ in plants was similar between regions of ecotype provenance, and it ranged from $9.1-11.8$ for $E$-plants and 11.8 to 16.2 for $E+$ plants. For three from 12 tested ecotypes there were no significant difference between $\mathrm{Cd}^{+2}$ concentration in $E+$ and $E-$ plants.

High copper concentration was found in aerial parts of $E+$ ecotypes 160, 273, and 873 (47.9, 40.6, and $37.4 \mathrm{mg} \cdot \mathrm{kg}^{-1}$, respectively). All mentioned values were significantly higher than in leaves of corresponding $E$ - plants. The average high concentration of $\mathrm{Cu}^{2+}$ ions in $E+$ plants (ca. $30 \mathrm{mg} \cdot \mathrm{kg}^{-1}$ ) was noted for central and southern regions, i.e., LUB and SWK. But the highest concentration of $\mathrm{Cu}^{2+}\left(34.7 \mathrm{mg} \cdot \mathrm{kg}^{-1}\right)$ was noted in $E$ - plants of ecotype 50, from POD region, which was the northern most exposed.
The effect of endophyte presence in perennial ryegrass plants resulted in different types of $E+$ plant reactions to elevated concentration of HM ions in the soil:

(i) $E+$ plants accumulated less HM ions from the soil than $E$-plants. In the experiment there were following ecotypes: 131 (all $\mathrm{HM}$ ions), $50\left(\mathrm{~Pb}^{2+}\right.$ and $\mathrm{Cu}^{2+}$ ions), 730 and $87\left(\mathrm{~Pb}^{2+}\right.$ ions $), 273$ and $227\left(\mathrm{Cd}^{2+}\right.$ ions);

(ii) $E+$ and $E-$ plants accumulated the same amounts of $\mathrm{HM}$ ions (no significant difference). Such was the case of ecotypes: $87\left(\mathrm{Cd}^{2+}\right.$ and $\mathrm{Cu}^{2+}$ ions $), 801\left(\mathrm{~Pb}^{2+}\right.$ and $\mathrm{Cu}^{2+}$ ions);

(iii) $E+$ plants accumulated a higher amount of HM ions from soil than $E$-plants: Ecotypes 60, 129, and 685 for all HM ions; ecotypes 45, 227, 273, and 873 for two different HM ions;

(iv) variable interaction depending on $\mathrm{HM}$ ion: Ecotype 730 higher concentration in $E$ - for $\mathrm{Pb}^{2+}$, higher concentration in $E+$ for $\mathrm{Cd}^{2+}$, no difference between $E+$ and $E-$ for $\mathrm{Cu}^{2+}$.

\section{Discussion}

There is increasing evidence that interactions of plants and microbes (including endophytes) play a critical role in metal phytoextraction and metal-mining, as they mediate different physicochemical and biological activities to facilitate ecological performances of the host plant (Muehe et al. 2015). The results of our studies revealed considerable variation in terms of the grass-fungus association's ability to cope with elevated concentration of HM ions in the soil. Mentioned 'variation' should be ascribed to the natural variation between host (perennial ryegrass), fungus and to their interaction. Spatial variation 
of mutualistic interactions between a host organism (grass plant) and infecting fungus (endophyte) through its intensity (endophyte frequency per locality) and production of toxic metabolite, i.e., ergovaline, has been previously described (Żurek et al. 2013, 2017).

Plants subjected to increased HM contents in soil were characterized by significantly higher values of the CCI and plant biomass - this could be explained based on soil fertility. The soil used for this experiment contained a low level of $\mathrm{Cu}^{2+}$ ions $\left(2.4 \mathrm{mg} \cdot \mathrm{kg}^{-1}\right)$ and high amounts of soil organic carbon (SOC), 13\%. The natural content of $\mathrm{Cu}^{2+}$ in soil was in the range of 15 to $40 \mathrm{mg} \cdot \mathrm{kg}^{-1}$ in the $0-20 \mathrm{~cm}$ soil horizon and concentration of $\mathrm{Cu}^{2+}$ below $3.0 \mathrm{mg} \cdot \mathrm{kg}^{-1}$ is usually defined as a deficit for grass species (Olszewska et al. 2008; Wyszkowska et al. 2013). In the presence of high organic matter content in the soil, the $\mathrm{Cu}^{2+}$ deficit for plants is quite frequent. Moreover, monocotyledonous plants (e.g., grasses) are particularly sensitive to $\mathrm{Cu}^{2+}$ deficit (Yamasaki et al. 2008). Unfortunately all these three facts together were met together in our experiment, therefore the addition of $\mathrm{Cu}$ to soil medium yielded better growth of HM treated plants, which was manifested in higher CCI values. The differences were not statistically significant for ecotypes collected from the southern region, except for 1 ecotype of $E+$ and 2 ecotypes of $E-$ which could be the result of adaptation to naturally occurring conditions of increased HM content in soil (Rodriguez et al. 2008).

$\mathrm{Chl} a$ fluorescence detection and parameters analyses $\left(F_{\mathrm{O}}, F_{\mathrm{M}}, F_{\mathrm{V}}, F_{\mathrm{V}} / F_{\mathrm{M}}, F_{\mathrm{V}} / F_{\mathrm{O}}\right.$, RCB/ABS, Area, $(1-V \mathrm{j}) / V \mathrm{j}$, $\left.\mathrm{P}_{\mathrm{I}}\right)$ are simple and widely recognized methods to assess the stress influence on plants (Żurek et al. 2014; Kalaji et al. 2016). Among fluorescence parameters measured in our experiment, $F_{\mathrm{O}}, F_{\mathrm{M}}, F_{\mathrm{V}}$, as well as the $F_{\mathrm{V}} / F_{\mathrm{M}}, F_{\mathrm{V}} / F_{\mathrm{O}}$ and $(1-V \mathrm{j}) / V \mathrm{j}$, were found to be significantly influenced by both HM ions addition and its interaction with endophyte status. As a reaction to stress, $F_{\mathrm{O}}$ value mostly increases, which is interpreted as lower efficiency of energy transfer between chlorophyll antennas in PS II, and our data follow reports in the literature (Prasad and Strzałka 1999). Although the increase of $F_{\mathrm{O}}$ was detected in the case of the majority of studied ecotypes, the $E+$ ecotypes, compared to $E$-, were characterized by lower values of this parameter pointing to the positive influence of Epichloë in the host plants, as was shown in studies on host orchard grass as well (Rozpądek et al. 2015). The $F_{\mathrm{M}}$ is decreasing in response to stresses due to the fact that not all electron acceptors in PS II can be reduced. Considering results obtained in our experiment, endophyte presence in plant tissues seems to induce stress to a plant, as reflected by a decrease of $F_{\mathrm{M}}$. The $F_{\mathrm{V}} / F_{\mathrm{O}}$ ratio, also used for the detection of PS II destruction upon stress, can descend from values of 4-5 down to 1 . According to the results obtained in this experiment, a slight but significant ( $<5 \%$ on average) decrease of $F_{\mathrm{V}} / F_{\mathrm{O}}$ ratio was detected, showing that the stress did not influence the photosynthetic machinery to a large extent (Kalaji and Łoboda 2010).

The parameter $F_{\mathrm{V}} / F_{\mathrm{M}}$ is one of the most commonly used in the evaluation of plant physiological status on the bases of fluorescence characteristics. For most healthy plants, it oscillates between 0.80 and 0.83 . In our experiment, it fluctuated in 0.78 and 0.81 ranges. Interestingly, HM ions induced a statistically important drop down in this parameter in $E+$ ecotypes originated from northern latitudes.

The distribution of points on the PCA graph indicates that the presence of HM in soil increased stress for plants as reflected by the $\mathrm{Chl} a$ parameter describing the efficiency of PS II. Points representing the efficiency of PS II in the presence or absence of HM in soil for $E+$ plants were separated over the $\mathrm{OX}$ axis. Considering the negative sign of correlation coefficients between factor 1 , factor 2 , and $\mathrm{Chl}$ a parameters, points on the left side of the OX axis (negative values of factor 1) represent the better status of plants than points on the right (positive values of factor 1). In the case of the absence of endophyte in host plants, there is also no clear separation of points representing the efficiency of PS II in the presence or absence of HM in soil.

Increased nutrient content due to endophyte presence was observed by many authors (Soto-Barajas et al. 2016; Malinowski et al. 2004; Zabalgogeazcoa et al. 2006). In contrast, an absence of endophyte effect for total $\mathrm{N}$ (Lewis et al. 1996) and Zn concentration (Monnet et al. 2005) was reported with a single perennial ryegrass genotype evaluated. In the current experiment, we have observed the whole range of possible reactions: from $E+$ plants accumulating less HM than $E$-plants, through no effect, to increased accumulation of one, two, or three HM ions from the soil by $E+$ plants. Detected differences resulted, probably not only from differences in the endophyte activities but also from strong interactions between the fungus and the host plant, which arose as a result of particular conditions in an origin site. In the current research, spatial aggregation of $E+$ plants able to uptake relatively higher amounts of the $\mathrm{HM}$ from the soil has been found for $\mathrm{Pb}^{2+}$ accumulation. Perennial ryegrass ecotypes collected from the SWK region (locations below the latitude $50.84 \mathrm{~N}$ ) demonstrated the ability for accumulation of relatively higher concentration of $\mathrm{Pb}^{2+}$ ions in $E+$ plants than those from the other regions. It could be presumed that it is in line with the natural concentration of $\mathrm{Pb}^{2+}$ in the soils from this region which was concentrated in average of $17.8 \mathrm{mg} \cdot \mathrm{kg}^{-1}$ of soil compared to $9.4-10.2 \mathrm{mg} \cdot \mathrm{kg}^{-1}$ of the soils from other sampling sites in our experiment (Table S1). Hesse et al. $(2003,2004)$ concluded that plant-endophyte associations are adapted to their native habitats via natural selection. As we have mentioned before, the natural content of the $\mathrm{HM}$, especially $\mathrm{Pb}^{2+}$ ions, in soil was higher in the SWK region than in other regions. Probably symbiota of this origin used to accumulate more 
$\mathrm{Pb}^{2+}$ than those coming from areas of low $\mathrm{Pb}^{2+}$ concentration. This could be further hypothesized that the whole microbiome of plants that came from soils of high $\mathrm{Pb}^{2+}$ concentration could be different from soils of low $\mathrm{Pb}^{2+}$ concentration. The role of the microbiome on plant health and HM tolerance has been recently widely analyzed and discussed (Dongchu et al. 2019; Ikram et al. 2018; Seneviratne et al. 2017).

The presence of HM tolerant endophytes could improve metals uptake and accumulation in hosting plants ( $\mathrm{Li}$ et al. 2012a, b). Endophyte colonization promoted $\mathrm{Cd}^{2+}$ ion accumulation in tall fescue (Ren et al. 2011) and also improved $\mathrm{Cd}^{2+}$ transport from the root to the shoot. Hesse et al. (2003, 2004) have also found higher abundances of infected perennial ryegrass genotypes on dry sites compared to wet sites and this has been confirmed in our previous research (Żurek et al. 2013, 2017). An abundance of endophyte-infected perennial ryegrass plants was significantly and negatively correlated with annual as well as winter precipitation (multiannual averages, 1950-2000) at localities of their origin. Considering the habitat of symbiota origin, for example, Dobrindt et al. (2013) reported higher incidences of Neotyphodium lolii at sites of limestone bedrock. Therefore, conditions at the place of host plant origin (both climatic and soil) may influence its ability to cope with abiotic stress (drought, soil acidity, toxic metals in soil). Differences observed between the host plants appear to depend on the endophyte and the host life histories, as well as on fungal and plant genotypes, abiotic and biotic environmental conditions, and their interactions (Saikkonen et al. 2013). Specific genotypic combinations of both host and endophyte determine the morphology and physiology of endophyte colonized grasses, as well as regulates how selective pressure acts on them (Hill et al. 1996).

\section{Conclusions}

Tested associations (fungus + host) exerted wide variation in response to the presence of an elevated concentration of lead, cadmium, and copper in the soil. In some cases, the presence of Epichloë sp. in perennial ryegrass tissues resulted in the increase of accumulation of above mentioned heavy metals in aerial parts of the host plants. Generally, in the presence of endophyte mycelium, an increased accumulation of cadmium and copper was found, but not for lead.

The phyto-beneficial effect of endophytes was strongly dependent on specific host-fungus associations, which in turn could be the effect of the host plants, i.e., ecotype provenance. However, results obtained in the experiment described above are not sufficient to draw conclusions on the relationship between the provenance of symbiota and their ability to accumulate heavy metals from the soil.
To achieve the best result of the phytoremediation of heavy metals, the choice of the most effective perennial ryegrass-Epichloë symbiosis should be based on their laboratory evaluation.

Abbreviations ANOVA: Analysis of variance; Area: Total complementary area between the fluorescence induction curve and $F_{\mathrm{M}}$ of OJIP curve; $\mathrm{CCl}$ : Chlorophyll content index; $\mathrm{Chl} a$ : Chlorophyll $a$; $E$ : East; $E+$ : Grass-endophyte association; $E-$ : Endophyte-free grass (non-colonized by endophyte); $F_{\mathrm{O}}$ : Minimal fluorescence; $F_{\mathrm{M}}$ : Maximal recorded fluorescence; $F_{\mathrm{V}}$ : Maximal variable fluorescence $\left(\mathrm{F}_{\mathrm{M}}-\mathrm{F}_{\mathrm{O}}\right) ; F_{\mathrm{V}} / F_{\mathrm{M}}$ : Maximum quantum efficiency of PSII photochemistry; $F_{\mathrm{V}} / F_{\mathrm{O}}$ : Driving force of light reactions; $(1-V \mathrm{j}) / V \mathrm{j}$ : Measure of forward electron transport; HM: Heavy metal; h: High; 1: Low; LUB: Lubelskie region; m: Medium; m.a.s.l: Meters above sea level; MAZ: Mazowieckie region; min: Mineral; $n$ : North; org: Organic; POD: Podlaskie region; PCA: Principal component analysis; $\mathrm{PI}_{\mathrm{ABS}}$ : Performance index; PS II: Photosystem II; RC/ABS: Amount of active reaction centers per absorption; SWK: ŚWiętokrzyskie region; $\mathrm{t}$ : T statistic; $T_{\mathrm{FM}}$ : Time needed to reach the maximal fluorescence

Supplementary Information The online version contains supplementary material available at https://doi.org/10.1007/s13353-021-00661-0.

\section{Declarations}

Competing interests The authors declare no competing interests.

Open Access This article is licensed under a Creative Commons Attribution 4.0 International License, which permits use, sharing, adaptation, distribution and reproduction in any medium or format, as long as you give appropriate credit to the original author(s) and the source, provide a link to the Creative Commons licence, and indicate if changes were made. The images or other third party material in this article are included in the article's Creative Commons licence, unless indicated otherwise in a credit line to the material. If material is not included in the article's Creative Commons licence and your intended use is not permitted by statutory regulation or exceeds the permitted use, you will need to obtain permission directly from the copyright holder. To view a copy of this licence, visit http://creativecommons.org/licenses/by/4.0/.

\section{References}

Avila PO, Barrow JR, Lucero ME, Aaltonen RE (2012) Relationship between plant lipid bodies and fungal endophytes. Terra Latinoamericana 30:39-46

Bacon CW, Palencia ER, Hinton DM (2015) Abiotic and biotic plant stress-tolerant and beneficial secondary metabolites produced by endophytic bacillus species. In: Arora NK (ed) Plant Microbes Symbiosis: Applied Facets. Springer India, New Delhi, pp 163-177

Barceló J, Poschenrieder C (1990) Plant water relations as affected by heavy metal stress: a review. J Plant Nutr 13:1-37

Bush LP, Wilkinson HH, Schardl CL (1997) Bioprotective alkaloids of grass-fungal endophyte symbioses. Plant Physiol 114(1):1-7

Clay K (1988) Fungal endophytes of grasses: a defensive mutualism between plants and fungi. Ecology 69:10-16

Clay K, Holah J (1999) Fungal endophyte symbiosis and plant diversity in successional fields. Science 285(5434):1742-1745 
Clijsters H, Van Assche F (1985) Inhibition of photosynthesis by heavy metals. Photosynth Res 7:31-40

Dobrindt L, Stroh HG, Isselstein J, Vidal S (2013) Infected-not infected: factors influencing the abundance of the endophyte Neotyphodium lolii in managed grasslands. Agr Ecosyst Environ 175:54-59

Dongchu G, Zhouzhou F, Shuyu L, Yangjiao M, Xianhong N, Fangping T, Xiawei P (2019) Changes in rhizosphere bacterial communities during remediation of heavy metal-accumulating plants around the Xikuangshan mine in southern China. Sci Rep 9:1947

Dupont PY, Eaton CJ, Wargent JJ, Fechtner S, Solomon P, Schmid J, Day RC, Scott B, Cox MP (2015) Fungal endophyte infection of ryegrass reprograms host metabolism and alters development. New Phytol 208:1227-1240

Farid M, Shakoor MB, Ehsan A, Ali S, Zubair M, Hanif MS (2013) Morphological, physiological and biochemical responses of different plant species to Cd stress. Int J Chem Biochem Sci 3:53-60

Hall JL (2002) Cellular mechanisms for heavy metal detoxification and tolerance. J Exp Bot 53(366):1-11

Hao G, Du X, Zhao F, Ji H (2010) Fungal endophytes-induced abscisic acid is required for flavonoid accumulation in suspension cells of Ginkgo biloba. Biotech Lett 32:305-314

Hesse U, Hahn H, Andreeva K, Forster K, Warnstorff K, Schoberlein W, Diepenbrock W (2004) Investigations on the influence of Neotyphodium endophytes on plant growth and seed yield of Lolium perenne genotypes. Crop Sci 44:1689-1695

Hesse U, Schöberlein W, Wittenmayer L, Förster K, Warnstorff K (2003) Effects of Neotyphodium endophytes on growth, reproduction and drought-stress tolerance of three Lolium perenne L. genotypes. Grass Forage Science 58:407-415

Hill NS, Pachon JG, Bacon CW (1996) Acremonium coenophialummediated short- and long-term drought acclimation in tall fescue. Crop Sci 36:665-672

Hossain MA, Piyatida P, da Silva JAT, Fujita M (2012) Molecular mechanism of heavy metal toxicity and tolerance in plants: central role of glutathione in detoxification and reactive oxygen species and methylglyoxal and heavy metal chelation. J Bot 1-37

Ikram M, Niaz A, Gul J, Farzana Gul J, Inayat Ur R, Amjad I, Hamayun M (2018) IAA producing fungal endophyte Penicillium roqueforti Thom., enhances stress tolerance and nutrients uptake in wheat plants grown on heavy metal contaminated soils. PLoS ONE 13(11):e0208150

Kalaji HM, Jajoo A, Oukarroum A, Brestic M, Zivcak M, Samborska IA, Cetner MD, Łukasik I, Goltsev V, Ladle RJ (2016) Chlorophyll a fluorescence as a tool to monitor physiological status of plants under abiotic stress conditions. Acta Physiol Plant 38:102

Kalaji M, Łoboda T (2010) Chlorophyll a fluorescence in studies of the physiological state of plants. $1^{\text {st }}$ ed.; SGGW Warszawa, Poland, pp. 117, ISBN: 978-83-7583-119-1 (in Polish).

Lewis G, Raistrick N, Bakken A, Macduff J (1996) Effect of infection by the endophytic fungus Acremonium lolii on growth and nitrogen uptake by perennial ryegrass (Lolium perenne) in flowing solution culture. Ann Appl Biol129:451-460

Li H, Wei D, Shen M, Zhou Z (2012a) Endophytes and their role in phytoremediation. Fungal Diversity 54:11-18

Li HY, Li DW, He CM, Zhou ZP, Mei T, Xu HM (2012b) Diversity and heavy metal tolerance of endophytic fungi from six dominant plant species in a $\mathrm{Pb}-\mathrm{Zn}$ mine wasteland in China. Fungal Ecol 5:309-315

Li X, Li W, Chu L, White JF Jr, Xiong Z, Li H (2016) Diversity and heavy metal tolerance of endophytic fungi from Dysphania ambrosioides, a hyperaccumulator from $\mathrm{Pb}-\mathrm{Zn}$ contaminated soils. J Plant Interact 11(1):186-192

Malinowski D, Zuo H, Belesky D, Alloush G (2004) Evidence for copper binding by extracellular root exudates of tall fescue but not perennial ryegrass infected with Neotyphodium spp. endophytes. Plant Soil 267:1-12

Monnet F, Vaillant N, Hitmi A, Sallanon H (2005) Photosynthetic activity of Lolium perenne as a function of endophyte status and zinc nutrition. Funct Plant Biol 32:131-139

Muehe E, Weigold P, Adaktylou I, Planer-Freidrich B, Kraemer U (2015) Rhizosphere microbial community composition affects cadmium and zinc uptake by the metal-hyperaccumulating plant Arabidopsis halleri. Appl Environ Microbiol 81:2173-2181

Nagabhyru P, Dinkins RD, Wood CL, Bacon CW, Schardl CL (2013) Tall fescue endophyte effects on tolerance to water-deficit stress. BMC Plant Biol 13:1-17

Olszewska M, Grzegorczyk S, Alberski J, Bałuch-Małecka A, Kozikowski A (2008) Effect of copper deficiency on gas exchange parameters. leaf greenness (SPAD) and yield of perrennial reygrass (Lolium perenne, L.) and ochard grass (Dactylis glomerata, L.). J Elementol 13:597-604

Paunov M, Koleva L, Vassilev A, Vangronsveld J, Goltsev V (2018) Effects of different metals on photosynthesis: cadmium and zinc affect chlorophyll fluorescence in durum wheat. Int J Mol Sci 19:787

Porter JK (1994) Chemical constituents of grass endophytes. In: White JF, Bacon CW (eds) Biotechnology of endophytic fungi of grasses. CRC Press, Boca Raton FL, pp 103-123

Prasad MNV, Strzałka K (1999) Impact of heavy metals on photosynthesis. In: Springer B (ed) heavy metal stress in plants: from molecules to ecosystems, Prasad MNV, Hagemeyer J. Berlin, Heidelberg, Heidelberg, pp 117-138

Rasmussen S, Parsons AJ, Fraser K, Xue H, Newman JA (2008) Metabolic profiles of Lolium perenne are differentially affected by nitrogen supply, carbohydrate content, and fungal endophyte infection. Plant Physiol 146:1440-1453

Ren A, Li C, Gao Y (2011) Endophytic fungus improves growth and metal uptake of Lolium arundinaceum Darbyshire ex. Schreb. Int J Phytoremediation 13:233-243

Rodriguez RJ, Henson J, Van Volkenburgh E, Hoy M, Wright L, Beckwith F, Kim YO, Redman RS (2008) Stress tolerance in plants via habitat-adapted symbiosis. ISME J 2:404-416

Rozpądek P, Wężowicz K, Nosek M, Ważny R, Tokarz K, Lembicz M, Miszalski Z, Turnau K (2015) The fungal endophyte Epichloë typhina improves photosynthesis efficiency of its host orchard grass (Dactylis glomerata). Planta 242:1025-1035

Saha D, Jackson M, Johnson-Cicalese J (1988) A rapid staining method for detection of endophyte fungi in turf and forage grasses. Phytopathology 78:237-239. https://doi.org/10.1094/Phyto-78-237

Saikkonen K, Gundel PE, Helander M (2013) Chemical ecology mediated by fungal endophytes in grasses. J Chem Ecol 39:962-968

Saikkonen K, Young CA, Helander M, Schardl CL (2016) Endophytic Epichloë species and their grass hosts: from evolution to applications. Plant Mol Biol 90:665-675

Schardl CL, Young CA, Faulkner JR, Florea S, Pan JL (2012) Chemotypic diversity of Epichloë, fungal symbionts of grasses. Fungal Ecol 5:331-344

Schardl CL, Young CA, Hesse U, Amyotte SG, Andreeva K, Calie PJ, Fleetwood DJ, Haws DC, Moore N, Oeser B, Panaccione DG, Schweri KK, Voisey CR, Farman ML, Jaromczyk JW, Roe BA, O'Sullivan DM, Scott B, Tudzynski P, An Z, Arnaoudova EG, Bullock CT, Charlton ND, Chen L, Cox M, Dinkins RD, Florea S, Glenn AE, Gordon A, Güldener U, Harris DR, Hollin W, Jaromczyk J, Johnson RD, Khan AK, Leistner E, Leuchtmann A, Li C, Liu J, Liu J, Liu M, Mace W, Machado C, Nagabhyru P, Pan J, Schmid J, Sugawara K, Steiner U, Takach JE, Tanaka E, Webb JS, Wilson EV, Wiseman JL, Yoshida R, Zeng Z (2013) Plantsymbiotic fungi as chemical engineers: multi-genome analysis of the Clavicipitaceae reveals dynamics of alkaloid loci. Plos Genetics 9(2):e1003323 
Seneviratne M, Seneviratne G, Madawala H, Vithanage M (2017) Role of rhizospheric microbes in heavy metal uptake by plants. In: Singh JS, Seneviratne G (eds) Agro-Environmental Sustainability. Publishing, Springer Int, pp 147-163

Sharma SS, Dietz J (2009) The relationship between metal toxicity and cellular redox imbalance. Trends Plant Sci 14:43-50

Singh LP, Singh GS, Tuteja N (2011) Unraveling the role of fungal symbionts in plant abiotic stress tolerance. Plant Signal Behav 6:175-191

Slaughter LC, Nelson JA, Carlisle E, Bourguignon M, Dinkins RD, Philips TD, McCulley RL (2018) Climate change and Epichloë coenophiala association modify belowground fungal symbioses of tall fescue host. Fungal Ecol 31:37-46

Soleimani M, Hajabbasi MA, Afyuni M, Mirlohi A, Borggaard OK, Holm P (2010) Effect of endophytic fungi on cadmium tolerance and bioaccumulation by Festuca arundinacea and Festuca pratensis. Int J Phytorem 12(6):535-549

Soto-Barajas MC, Zabalgogeazcoa I, Gómez-Fuertes J, GonzálezBlanco V, Vázquez-de-Aldana BR (2016) Epichloë endophytes affect the nutrient and fiber content of Lolium perenne regardless of plant genotype. Plant Soil 405:265-277

StatSoft Inc. (2014) STATISTICA (data analysis software system), version 12

Strehmel N, Mönchgesang S, Herklotz S, Krüger S, Ziegler J, Scheel D (2016) Piriformospora indica stimulates root metabolism of Arabidopsis thaliana. Int J Molecul Sci 17:1091

Tadych M, Bergen MS, White JF (2014) Epichloë spp. associated with grasses: new insights on life cycles, dissemination and evolution. Mycologia 106(2):181-201

Terelak H (2007) The content of trace metals and sulfur in the soils of agricultural land in Poland and soils pollution with these elements. In Vademecum of Soils Classifier, Woch, F., Ed. IUNGPIB: Puławy, pp 224 - 240, ISBN 8389576023 (in Polish)

Thijs S, Sillen W, Weyens N, Vangronsveld J (2017) Phytoremediation: state-of-the-art and a key role for the plant microbiome in future trends and research prospects. Int J Phytorem 19:23-38
Van Assche F, Clijsters H (1990) Effects of metals on enzyme activity in plants. Plant, Cell Environ 13:195-206

Wiewióra B, Żurek G, Pańka D (2015a) Is the vertical transmission of Neotyphodium lolii in perennial ryegrass the only possible way to the spread of endophytes? Plos ONE 10(2):e011723

Wiewióra B, Żurek G, Żurek M (2015b) Endophyte-mediated disease resistance in wild population-s of perennial ryegrass (Lolium perenne L.). Fungal Ecol 15:1-8

Wyszkowska J, Borowik A, Kucharski M, Kucharski J (2013) Effect of cadmium, copper and zinc on plants, soil microorganisms and soil enzymes. J Elementol 4:769-796

Yamasaki H, Pilon M, Shikanai T (2008) How do plants respond to copper deficiency? Plant Signal Behav 3(4):231-232

Zabalgogeazcoa I, Garcia Ciudad A, Vázquez de Aldana B, Garcia Criado B (2006) Effects of the infection by the fungal endophyte Epichloë festucae in the growth and nutrient content of Festuca rubra. Eur J Agron 24:374-384

Żurek G, Rybka K, Pogrzeba M, Krzyżak J, Prokopiuk K (2014) Chlorophyll a fluorescence in evaluation of the effect of heavy metal soil contamination on perennial grasses. PLoS ONE 9(3):e91475

Żurek G, Wiewióra B, Gozdowski D (2013) Relations between bioclimatic variables and endophytes colonization of grasses in Poland. Fungal Ecol 6:554-556

Żurek G, Wiewióra B, Żurek M, Łyszczarz R (2017) Environmental effect on Epichloë endophyte occurrence and ergovaline concentration in wild populations of forage grasses in Poland. Plant Soil 410:383-399

Publisher's note Springer Nature remains neutral with regard to jurisdictional claims in published maps and institutional affiliations. 